\title{
Differences in clinical variables and risk factors between patients with osteoarthritis and osteoarthrosis of the temporomandibular joint (TMJ)
}

\author{
Rafael Poveda-Roda ${ }^{1}$, Jose Vicente Bagán ${ }^{2}$, Jose María Sanchís ${ }^{1}$. \\ ${ }^{1}$ Staff physician. Department of Stomatology. Valencia University General Hospital. Valencia. \\ ${ }^{2}$ Head of the Department of Stomatology. Valencia University General Hospital. Valencia. Chairman of Oral Medicine. Valencia \\ University Medical and Dental School. Valencia (Spain).
}

Correspondence:

Servicio de Estomatología

Hospital General Universitario de Valencia

Tres Cruces s/n, 46014 - Valencia (Spain)

E-mail: poveda@uv.es

Poveda-Roda R, Bagán JV, Sanchís JM. Differences in clinical variables and risk factors between patients with osteoarthritis and osteoarthrosis of the temporomandibular joint (TMJ). J Clin Exp Dent. 2011;3(4):e303-9. http://www.medicinaoral.com/odo/volumenes/v3i4/jcedv3i4p303.pdf

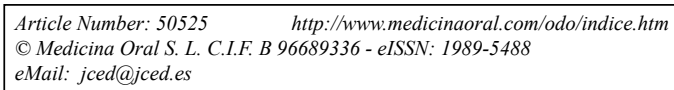

\begin{abstract}
Objective: To study differences in risk factors and clinical variables between a group of patients with osteoarthritis and a group with osteoarthrosis of the temporomandibular joint.

Material and methods: Thirty-five patients ( 32 women and 3 men) (mean age $53 \pm 18$ years), 21 (60\%) with a diagnosis of osteoarthrosis (mean age $54.7 \pm 20.2$ years) and $14(40 \%)$ with a diagnosis of osteoarthritis (mean age $51.7 \pm 16.9$ years), were studied. The two groups were compared with each other and also with the group of 164 patients with temporomandibular joint pathology from which they were drawn. An evaluation was made of the demographic variables, risk factors (parafunctions, posterior occlusal contacts, sleep disturbances and psychoactive medication), clinical manifestations (pain, joint sounds, limitation of mandibular movements) and panoramic X-ray and magnetic resonance imaging alterations.

Results: None of the studied variables showed statistically significant differences between osteoarthritis and osteoarthrosis. Age was significantly older among the patients with osteoarthritis/osteoarthrosis than in the general group of patients with temporomandibular joint pathology (36.9 \pm 17.2$)(\mathrm{F}=20.1 ; \mathrm{p}=0.000)$. The time from appearance of the symptoms to medical consultation (35.9 \pm 41.8 months) was significantly longer in patients with osteoarthritis $(\mathrm{F}=3.95 ; \mathrm{p}=0.049)$. The number of posterior occlusal contacts $(5.2 \pm 3.0)$, maximum aperture (32.5 \pm 6.5 $\mathrm{mm}$ ), and the frequency of parafunctions $(42.9 \%)$ were significantly lower in the group of patient with osteoarthritis $\left(\mathrm{F}=6.2 \mathrm{p}=0.01 ; \mathrm{F}=4.45 \mathrm{p}=0.04 ; \chi^{2}=4.85 \mathrm{p}=0.03\right)$ than in the group of patients with temporomandibular joint pathology from which they were drawn.

Conclusions: No epidemiological or clinical differences were observed between osteoarthritis and osteoarthrosis, though both processes - particularly osteoarthritis - showed differences with respect to the group of patients with temporomandibular joint pathology from which they were drawn.
\end{abstract}

Key Words: Osteoarthritis, osteoarthrosis, arthritis, arthrosis, TMD, RDC/TMD, temporomandibular. 


\section{Introduction}

Temporomandibular joint (TMJ) disease comprises a heterogeneous group of syndromes. Most of them can be included among the following categories: joint disc alterations, inflammatory or degenerative processes, or alterations of the joint-related muscles (1). The degenerative disorders of the TMJ do not differ physiologically or histologically from those seen in the large body joints: following an initial phase characterized by cell proliferation and increased metabolic activity in which active joint repair takes place, we observe progressive collagen destructurization and gradual loss of cartilage, which begins to show fissures. This disappearance of the cartilage leaves the underlying bone as the joint surface (2).

The publication in 1992 of the Research Diagnostic Criteria for Temporomandibular Disorders (RDC/TMD) (3) provided clinicians and investigators with a precise and reliable tool for diagnosing the most common alterations of the TMJ. Group III of axis I of this classification includes the subcategories arthralgia, osteoarthritis and osteoarthrosis. The latter is defined as a degenerative disorder in which the joint shape and structure is altered, while osteoarthritis is an inflammatory condition associated to a degenerative process. This inflammatory condition clinically manifests as arthralgia, which is defined as pain and tenderness in the joint capsuleand/or the synovial lining of the TMJ.

The present study was designed to explore differences in clinical variables and risk factors between patients with osteoarthritis and patients with osteoarthrosis of the TMJ, and to determine whether the two groups show differences in these same variables with respect to the group of patients with TMJ pathology from which they were drawn.

\section{Material and methods}

The study was approved by the Clinical Research Ethics Committee of Valencia University General Hospital (Valencia, Spain), and all patients signed the corresponding informed consent form. The diagnosis of osteoarthritis and osteoarthrosis was based on the clinical criteria of axis I of the RDC/TMD (3). The study group was achieved from among 164 patients referred to the hospital for evaluation and treatment of signs and symptoms compatible with pathology of the TMJ in the period between September 2008 and November 2009. Thirty-five patients ( 32 women and 3 men) (mean age $53 \pm 18$ years), $21(60 \%)$ with a diagnosis of osteoarthrosis (mean age $54.7 \pm 20.2$ years) and $14(40 \%)$ with a diagnosis of osteoarthritis (mean age $51.7 \pm 16.9$ years), were studied. The two groups included cases with both single and multiple diagnoses. Comparisons were established between the two groups and also with the series of patients with TMJ pathology from which they were drawn. Following the protocol designed for the study, we evalua- ted demographic variables, risk factors (parafunctions, posterior occlusal contacts, sleep disturbances and psychoactive medication), clinical manifestations (pain, joint sounds, limitation of mandibular movements), time from appearance of the symptoms to hospital consultation, exploration of the painful or tender points, measurement of mandibular movements, and alterations in the panoramic X-ray ( $\mathrm{P}-\mathrm{Xr}$ ) and magnetic resonance imaging (MRI) studies.

The clinical diagnosis of osteoarthrosis was based on the auscultation of crepitation as the expression of friction between two bone surfaces moving against each other without interpositioned cartilage (4). In turn, and in addition to crepitation, the diagnosis of osteoarthritis was based on clinical manifestations compatible with the diagnosis of arthralgia: pain in response to palpation of the lateral or posterior pole of one or both TMJs, together with patient complaint of pain in the articular zone, pain at maximum active aperture, pain at maximum forced passive aperture, or pain during lateralization movements. In our study we used only clinical variables to establish the diagnosis; evaluation of the P-Xr and MRI images was posterior, and although these imaging evaluations could influence patient management, they did not modify the clinical diagnosis previously established to the effects of the study. All patients underwent $\mathrm{P}-\mathrm{Xr}$ study (9200 Orthoralix DDE Gendex Dental Systems 901 West Oakton Street Des Plaines, IL, USA), and an MRI evaluation was requested (Signa 1.5 Tesla MRI, GE, Milwaukee, WI, USA), though the latter only proved possible in 24 patients. In the $\mathrm{P}-\mathrm{Xr}$ studies, the TMJs were evaluated by a single examiner. Intra-examiner concordance as established by the kappa index was 0.61 . Evaluation of the MRI images in turn was based on the report prepared by the imaging specialist. In those cases in which some osteoarthrosis criteria had not been evaluated, and in which discrepancies were observed between what we saw in the images and the report delivered by the Radiology Department, a new evaluation by an imaging specialist was requested, and this was then taken to be the final verdict. No inter- or intra-examiner concordance testing was made in the case of the MRI evaluation.

A frequencies and proportions descriptive study was made of the qualitative variables, while means and standard deviations were calculated for the quantitative variables. Comparisons between groups were based on the Fisher exact test and chi-squared test for contrasting qualitative variables with two categories, while analysis of variance (ANOVA) was used for the comparison of quantitative variables for independent samples. The SPSS (SPSS Inc. Chicago Ill) version 15.0 statistical package was used throughout. 


\begin{tabular}{|c|l|l|}
\hline RDC/TMD diagnosis & $\mathbf{N}$ & $\mathbf{\%}$ \\
\hline Myofascial pain & 16 & $9.8 \%$ \\
\hline Disc displacement with reduction & 23 & $14.0 \%$ \\
\hline Disc displacement without reduction & 5 & $3.0 \%$ \\
\hline Arthralgia & 14 & $8.5 \%$ \\
\hline Osteoarthritis & 8 & $4.9 \%$ \\
\hline Osteoarthrosis & 15 & $9.1 \%$ \\
\hline Multiple diagnoses & 51 & $31.1 \%$ \\
\hline Without RDC/TMD diagnosis & 32 & $19.5 \%$ \\
\hline
\end{tabular}

Table 1. Diagnoses of the patients with temporomandibular joint disorders included in the study.

\section{Results}

Table 1 shows the distribution by diagnoses of the patients referred to our Department because of temporomandibular joint dysfunction. Osteoarthritis was diagnosed in $8.5 \%$ and osteoarthrosis in $12.8 \%$. Some patients had multiple diagnoses (as contemplated by the RDC/TMD). This explains why the number of patients in Table 1 in the osteoarthritis and osteoarthrosis groups ( 8 and 15 , respectively) is smaller than the number of patients in the two study groups (14 and 21).

None of the analyzed variables showed statistically significant differences between osteoarthritis and osteoarthrosis, though the differences between some of the variables (maximum mandibular unassisted opening $\mathrm{p}=0.06$, parafunctions $\mathrm{p}=0.09$ ) could be of clinical relevance (Table 2). Osteoarthritis was diagnosed in a 19year-old woman, and osteoarthrosis was diagnosed in an 18 -year-old woman. There were alterations in the panoramic X-rays in $64.3 \%$ of the patients with osteoarthritis and in $57.1 \%$ of the patients with osteoarthrosis, while MRI alterations were recorded in $90 \%$ of the patients with osteoarthritis and in $100 \%$ of the patients with osteoarthrosis.

Comparisons were also made of the patients with osteoarthritis or osteoarthrosis versus the group of patients with TMJ dysfunction from which they were drawn (Table 3). Age was significantly older in the patients with osteoarthritis $(54.1 \pm 20.2$ years $)$ and osteoarthrosis $(50.8 \pm 17.9$ years) than in the rest ( $36.9 \pm 17.2$ years). The time from symptoms onset to consultation ( $35.9 \pm 41.8$ months) was significantly greater in the patients with osteoarthritis $(\mathrm{F}=3.95 ; \mathrm{p}=0.049)$. The number of posterior occlusal contacts $(5.2 \pm 3.0)$, maximum opening $(32.5 \pm 6.5 \mathrm{~mm})$ and the frequency of parafunctions (42.9\%) were significantly lower in the group of patients with osteoarthritis $\left(\mathrm{F}=6.2 \mathrm{p}=0.01 ; \mathrm{F}=4.45 \mathrm{p}=0.04 ; \chi^{2}=4.85 \mathrm{p}=0.03\right)$ than in those with TMJ dysfunction. The frequency of alterations in the panoramic X-rays among the patients with osteoarthritis (64.3\%) and osteoarthrosis (57.1\%) was significantly greater than in the reference series from which they were drawn $(7 \%)(p=0.000$ in both cases).

\section{Discussion}

In a previous study involving a group of 850 patients with TMJ disorders different from those evaluate here, we found $85.8 \%$ of the total to be women, and $86 \%$ of the subgroup of patients with a principal diagnosis of osteoarthrosis also were females (5). An even higher female proportion can be found in an article published in 2004, involving a group of 16 patients diagnosed with osteoarthrosis subjected to MRI evaluation, in which $93.8 \%$ of the patients were women (6). In this context, our data match up with most of those found in the literature, with persistent female proportions of over $80 \%$ (7). The locally produced estrogens exert a decisive influence upon cartilage physiology, and it has been postulated that alterations of these hormones could be the cause of temporomandibular joint dysfunction (8) - though no estrogen-binding sites have been found in the bilaminar tissue of the posterior ligament of the TMJ (9).

In our study, $63.4 \%$ of the patients with osteoarthritis, $47.5 \%$ of the patients with osteoarthrosis, and $40.3 \%$ of the patients with other TMJ dysfunctions reported sleep disturbances, most often in the form of light sleep (sleep interruptions) and insufficient sleep. The frequency observed in our study in osteoarthritis and osteoarthrosis is clearly superior to that reported by Smith et al. (10), and is also greater than the frequency reported in the general population, where the prevalence is in the order of $37 \%$ (11). Abad et al. (12) found sleep disturbances in $71 \%$ of their patients with arthrosis and an age of 55 years or older.

The use of antidepressants in women with a diagnosis of "muscle disorder" and the use of antidepressants (23\%), tranquilizers (6\%) and sleeping pills (7\%) in women with a diagnosis of "joint disorder" is significantly greater than in the general population (13). In our study, 47.6\% of the patients with a diagnosis of osteoarthrosis used some type of psychoactive medication, versus $28.0 \%$ of the patients with other types of TMJ dysfunction. The difference was not statistically significant $(p=0.06)$, though it did mark a clear clinical tendency.

There is some evidence that a loss of teeth in posterior sectors, particularly when several quadrants are affected, is associated with an increased prevalence of TMJ disease (14). Our findings show the number of posterior occlusal contacts between premolars and molars in both arches to be significantly lower in the group of patients 


\begin{tabular}{|c|c|c|c|c|}
\hline & Osteoarthritis & Osteoarthrosis & Test & Significance \\
\hline Age & $54.7 \pm 20.2$ years & $51.7 \pm 16.9$ years & $\mathrm{F}=0.71$ & $\mathrm{p}=0.71$ \\
\hline Time from symptoms onset to first visit & $35.9 \pm 41.8$ & $30.2 \pm 46.0$ & $\mathrm{~F}=0.13$ & $\mathrm{p}=0.71$ \\
\hline Maximum aperture & $32.5 \pm 6.4 \mathrm{~mm}$ & $37.8 \pm 8.0 \mathrm{~mm}$ & $\mathrm{~F}=3.86$ & $\mathrm{p}=0.06$ \\
\hline Light lateralization & $5.1 \pm 3.9 \mathrm{~mm}$ & $5.6 \pm 4.3 \mathrm{~mm}$ & $\mathrm{~F}=8.11$ & $\mathrm{p}=0.06$ \\
\hline Left lateralization & $5.0 \pm 3.7 \mathrm{~mm}$ & $7.0 \pm \pm 3.9 \mathrm{~mm}$ & $\mathrm{~F}=1.59$ & $\mathrm{p}=0.22$ \\
\hline Posterior occlusal contacts & $5.2 \pm 3.0$ & $5.9 \pm 2.5$ & $\mathrm{~F}=0.46$ & $\mathrm{p}=0.51$ \\
\hline Right posterior contacts & $2.6 \pm 1,7$ & $2.9 \pm 1.5$ & $\mathrm{~F}=0.51$ & $\mathrm{p}=0.48$ \\
\hline Left posterior contacts & $2.6 \pm 1.5$ & $2.9 \pm 1.8$ & $\mathrm{~F}=0.35$ & $\mathrm{p}=0.56$ \\
\hline Sex & $14.3 \% 0^{\pi}$ & $4.8 \% \overbrace{}^{\Uparrow}$ & Fischer & $\mathrm{p}=0.35$ \\
\hline Sleep disturbances & $63.4 \%$ & $47.5 \%$ & Fischer & $\mathrm{p}=0.67$ \\
\hline $\begin{array}{l}\text { Psychoactive medication (anxiolytics, } \\
\text { sleeping pills, antidepressants) }\end{array}$ & $28.6 \%$ & $47.6 \%$ & Fischer & $\mathrm{p}=0.22$ \\
\hline $\begin{array}{l}\text { Parafunctions } \\
\text { Clenching } \\
\text { Chewing gum } \\
\text { Nails }\end{array}$ & $\begin{array}{l}42.9 \% \\
35.6 \% \\
14.3 \% \\
7.1 \%\end{array}$ & $\begin{array}{l}71.4 \% \\
61.9 \% \\
14.3 \% \\
9.1 \%\end{array}$ & & $\begin{array}{l}p=0.09 \\
p=0.12 \\
p=0.68 \\
p=0.65\end{array}$ \\
\hline $\begin{array}{l}\text { Reason for consultation } \\
\text { Noise } \\
\text { Pain } \\
\text { Limited aperture } \\
\end{array}$ & $\begin{array}{l}0 \% ; 35.7 \% \\
42.9 \% ; 57.1 \% \\
0 \% ; 28.6 \% \\
\end{array}$ & $\begin{array}{l}14.3 \% ; 28.6 \% \\
38.1 \% ; 23.8 \% \\
19.0 \% ; 9.5 \% \\
\end{array}$ & $\chi^{2}=9.26$ & $\mathrm{p}=0.16$ \\
\hline Pain in response to TMJ palpation & --------------- & $14,3 \%$ & & \\
\hline Pain in response to muscle palpation & $61.9 \%$ & $85.7 \%$ & Fischer & $\mathrm{p}=0.13$ \\
\hline Number of tender muscle points & $3.0 \pm 2.1$ & $1.9 \pm 2.1$ & $\mathrm{~F}=1.83$ & $\mathrm{p}=0.19$ \\
\hline $\begin{array}{l}\text { P-Xr alterationse } \\
\text { Flattening } \\
\text { Osteophytes }\end{array}$ & $\begin{array}{l}100 \% \\
63.6 \% \\
8.2 \%\end{array}$ & $\begin{array}{l}84.6 \% \\
38.5 \% \\
7.8 \%\end{array}$ & & $\begin{array}{l}p=0.39 \\
p=0.16 \\
p=0.89\end{array}$ \\
\hline $\begin{array}{l}\text { MRI alterations§ } \\
\text { Flattening } \\
\text { Osteophytes } \\
\text { Erosion } \\
\text { DDWR\# } \\
\text { DDWoR• }\end{array}$ & $\begin{array}{l}90.0 \% \\
90.9 \% \\
81.8 \% \\
45.5 \% \\
27.3 \% \\
63.6 \% \\
\end{array}$ & $\begin{array}{l}100 \% \\
76.9 \% \\
76.9 \% \\
30.8 \% \\
15.4 \% \\
53.8 \% \\
\end{array}$ & & $\begin{array}{l}p=0.46 \\
p=0.65 \\
p=0.89 \\
p=0.62 \\
p=2.35\end{array}$ \\
\hline
\end{tabular}

Panoramic X-rays ${ }^{\S}$ Magnetic resonance imaging \# Disc displacement with reduction. $\bullet$ disc displacement without reduction

Table 2. Comparison between osteoarthritis and osteoarthrosis.

with osteoarthritis $(5.2 \pm 3.0)$ than in the rest of patients with other TMJ alterations (6.8 \pm 2.1 ) (Table 2).

Panoramic X-rays are of limited usefulness in the diagnosis of the diseases considered in the present study and in general in the diagnosis of pathology of the TMJ as is evidenced by studies in which very low inter-examiner concordances have been reported (kappa $=0.16$ ), with positive concordance percentages of $19 \%$ in the diagnosis of osteoarthrosis (15) (Figure 1). In our study the intra-examiner concordance (kappa index) was 0.61 , and alterations were seen in $63.4 \%$ of the patients with osteoarthritis and in $57.1 \%$ of those with osteoarthrosis. MRI offers marginal (low) sensitivity in the diagnosis of osteoarthritis and osteoarthrosis of the TMJ (15). However, it is reliable in assessing the soft tissue alterations and joint effusion (Figure 2); as a result, MRI has been used as a complementary exploration in our study. Condylar flattening observed by MRI showed no significant differences in relation to the presence or absence of degenerative bone changes (16), though we observed it in $90.9 \%$ and $75 \%$ of our patients, respectively (Table 2 ). In only one of the 14 patients showing disc displacement without reduction at MRI was a clinical diagnosis of disc displacement without reduction made - thus reflecting low sensitivity on the part of the clinical components of the RDC/TMD for the diagnosis of alterations in disc position associated to osteoarthritis and osteoarthrosis (17). It remains unclear whether disc displacement without reduction is a cause or effect of the osteoarthrosis phenomena. 


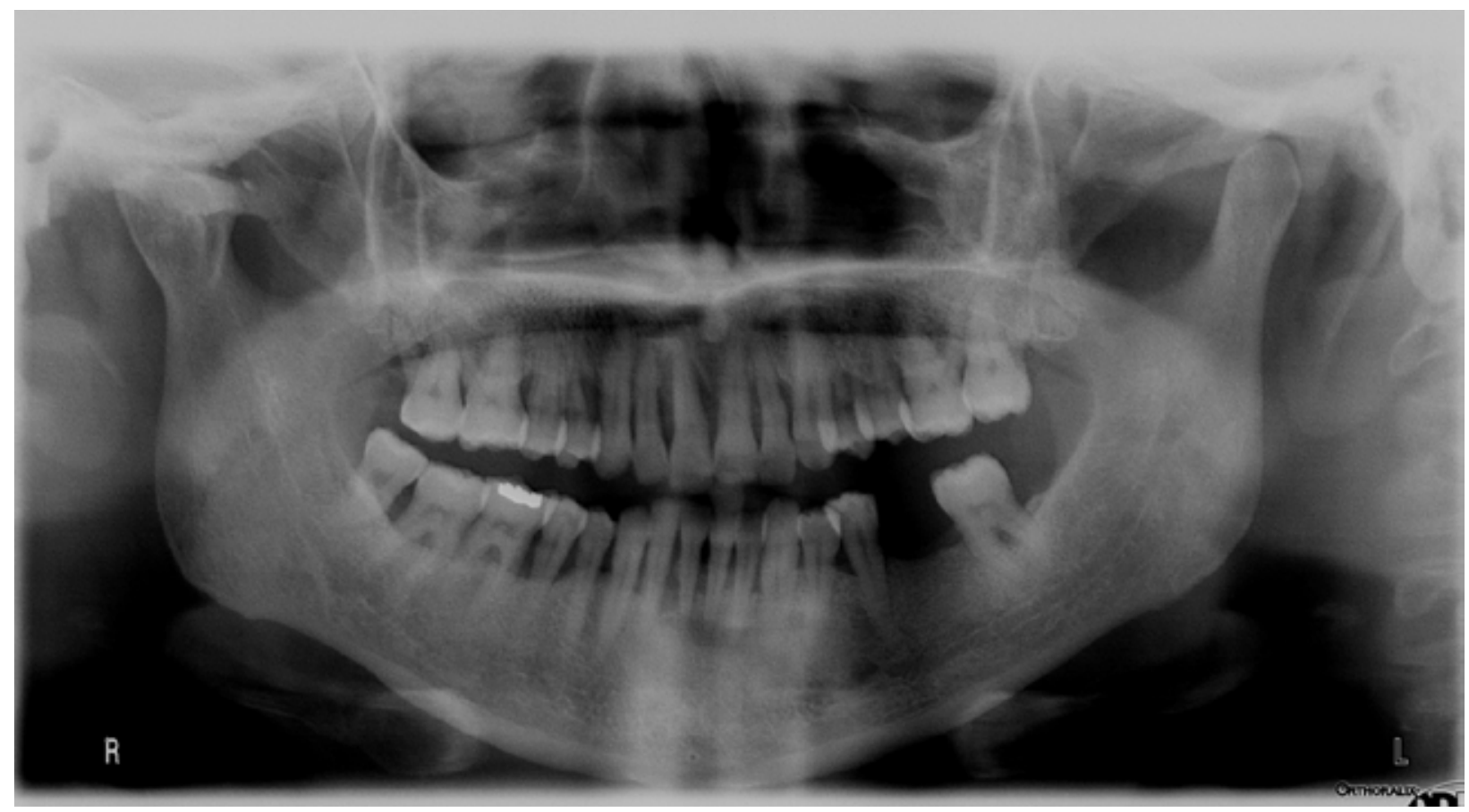

Fig.1. Suggestive signs of right temporomandibular joint osteoarthrosis.

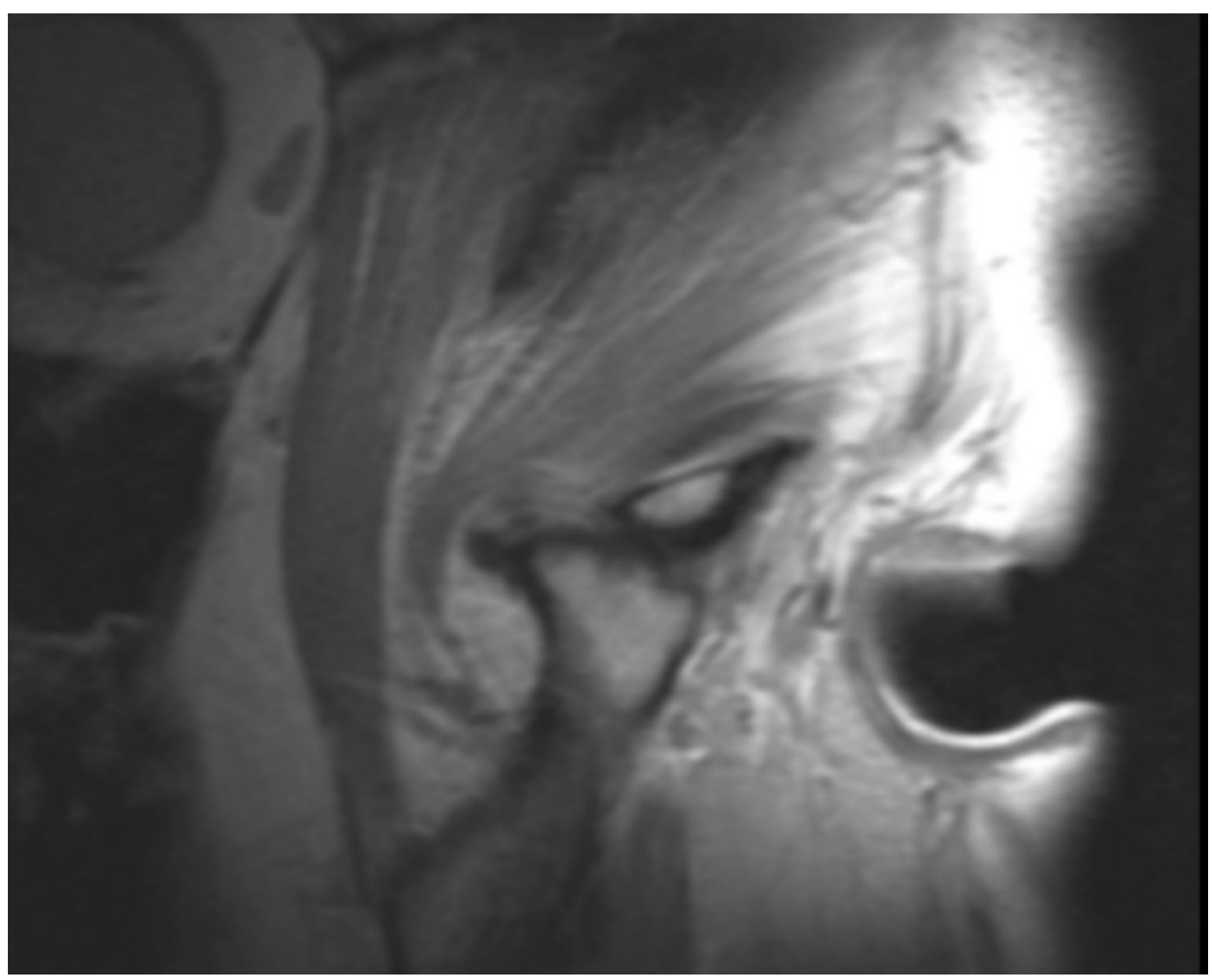

Fig. 2. Osteoarthrosis of the temporomandibular joint and disc displacement without reduction, in oblique sagittal MRI. 


\begin{tabular}{|c|c|c|c|c|c|c|}
\hline $\begin{array}{l}\text { Comparisons } \\
\text { Variables }\end{array}$ & $\begin{array}{l}\text { Osteoarthritis } \\
\text { vs. TMD }\end{array}$ & $\begin{array}{c}\text { Test }+ \\
\text { p-value }\end{array}$ & $\begin{array}{l}\text { Osteoarthrosis } \\
\text { vs. TMD }\end{array}$ & $\begin{array}{l}\text { Test }+ \\
\text { p-value }\end{array}$ & $\begin{array}{l}\text { Osteoarthritis- } \\
\text { osteoarthrosis } \\
\text { vs. TMD }\end{array}$ & $\begin{array}{l}\text { Test }+ \\
\text { p-value }\end{array}$ \\
\hline Age (years) & $\begin{array}{c}54.1 \pm 20.2 \text { vs. } \\
38.9 \pm 18,1 \\
\end{array}$ & $\begin{array}{l}F=8.83 \\
\mathbf{p}=\mathbf{0 . 0 0 3}\end{array}$ & $\begin{array}{c}50.8 \pm 17.9 \text { vs. } \\
38.6 \pm 18.2 \\
\end{array}$ & $\begin{array}{l}F=18.03 \\
\mathbf{p}=\mathbf{0 . 0 0 5}\end{array}$ & $\begin{array}{c}52.1 \pm 19.7 \text { vs. } \\
36.9 \pm 17.2 \\
\end{array}$ & $\begin{array}{l}F=20.12 \\
\mathbf{p}=\mathbf{0 . 0 0 0}\end{array}$ \\
\hline $\begin{array}{l}\text { Time to first visit (mon- } \\
\text { ths) }\end{array}$ & $\begin{array}{c}35.9 \pm 41.8 \text { vs. } \\
19.7 \pm 29.7\end{array}$ & $\begin{array}{l}F=3.95 \\
\mathbf{p}=\mathbf{0 . 0 4 9}\end{array}$ & $\begin{array}{c}29.0 \pm 45.2 \text { vs. } \\
21.0 \pm 29.2\end{array}$ & $\begin{array}{l}F=1.86 \\
p=0.17\end{array}$ & $\begin{array}{c}27.4 \pm 35.8 \text { vs. } \\
19.3 \pm 27.2\end{array}$ & $\begin{array}{c}\mathrm{F}=2.10 \\
\mathrm{p}=0.15\end{array}$ \\
\hline Maximum opening (mm) & $\begin{array}{c}32,5 \pm 6,5 \text { vs. } \\
37.8 \pm 8.5\end{array}$ & $\begin{array}{l}\mathrm{F}=4.45 \\
\mathbf{p}=\mathbf{0 . 0 4}\end{array}$ & $\begin{array}{c}38.8 \pm 7.3 \text { vs. } \\
37.2 \pm 8.6 \\
\end{array}$ & $\mathrm{~F}=0.68 ; \mathrm{p}=0.4$ & $\begin{array}{c}36.5 \pm 7.6 \mathrm{vs} . \\
37.6 \pm 8.7 \\
\end{array}$ & $\begin{array}{c}\mathrm{F}=0.45 \\
\mathrm{p}=0.51\end{array}$ \\
\hline Right lateralization & $\begin{array}{c}5,1 \pm 3.9 \text { vs. } \\
7.3 \pm 10.0\end{array}$ & $\begin{array}{l}\mathrm{F}=0.36 \\
\mathrm{p}=0.55\end{array}$ & $\begin{array}{c}5.8 \pm 4.1 \text { vs. } \\
7.3 \pm 10.3 \\
\end{array}$ & $\mathrm{~F}=0.4 ; \mathrm{p}=0.53$ & $\begin{array}{c}5.6 \pm 4.0 \mathrm{vs} \\
7.5 \pm 10.7 \\
\end{array}$ & $\begin{aligned} \mathrm{F} & =0.85 \\
\mathrm{p} & =0.37\end{aligned}$ \\
\hline Left lateralization & $\begin{array}{c}5,0 \pm 3.7 \text { vs. } \\
7.3 \pm 2.6\end{array}$ & $\begin{array}{l}\mathrm{F}=5.8 \\
\mathbf{p}=\mathbf{0 . 0 2}\end{array}$ & $\begin{array}{c}7.1 \pm 3.7 \mathrm{vs} . \\
7.1 \pm 2.6\end{array}$ & $\begin{array}{l}\mathrm{F}=0.01 \\
\mathrm{p}=0.98\end{array}$ & $\begin{array}{c}6.4 \pm 3.8 \text { vs. } \\
7.3 \pm 2.4\end{array}$ & $\begin{array}{c}\mathrm{F}=2.21 \\
\mathrm{p}=0.14\end{array}$ \\
\hline $\begin{array}{l}\text { Posterior occlusal } \\
\text { contacts }\end{array}$ & $\begin{array}{l}5.2 \pm 3.0 \mathrm{vs} \\
6.8 \pm 2.1\end{array}$ & $\begin{array}{l}F=6.2 \\
\mathbf{p}=\mathbf{0 . 0 1}\end{array}$ & $\begin{array}{c}5.9 \pm 2.5 \mathrm{vs} \\
6.8 \pm 2.2\end{array}$ & $\mathrm{~F}=2.74 ; \mathrm{p}=0.1$ & $\begin{array}{c}5.6 \pm 2.7 \text { vs. } \\
7.0 \pm 2.0\end{array}$ & $\begin{array}{l}F=9.51 \\
\mathbf{p}=\mathbf{0 . 0 0 2}\end{array}$ \\
\hline Right posterior contacts & $\begin{array}{c}2.6 \pm 1.7 \text { vs. } \\
3.5 \pm 1.1 \\
\end{array}$ & $\begin{array}{c}F=6.63 \\
\mathbf{p}=\mathbf{0 . 0 1}\end{array}$ & $\begin{array}{c}3.0 \pm 1.5 \text { vs. } \\
3.5 \pm 1.1 \\
\end{array}$ & $\begin{array}{c}\mathrm{F}=3.25 \\
\mathrm{p}=0.07\end{array}$ & $\begin{array}{c}2.8 \pm 1.6 \text { vs. } \\
3.5 \pm 1.0 \\
\end{array}$ & $\begin{array}{l}F=10.7 \\
\mathbf{p}=\mathbf{0 . 0 1}\end{array}$ \\
\hline Left posterior contacts & $\begin{array}{c}2.6 \pm 1.4 \text { vs. } \\
3.4 \pm 1.3 \\
\end{array}$ & $\begin{array}{l}\mathrm{F}=5.31 \\
\mathbf{p}=\mathbf{0 . 0 2}\end{array}$ & $\begin{array}{c}3.0 \pm 1.2 \text { vs. } \\
3.4 \pm 1.2 \\
\end{array}$ & $\begin{array}{l}\mathrm{F}=2.26 \\
\mathrm{p}=0.13\end{array}$ & $\begin{array}{c}2.8 \pm 1.3 \text { vs. } \\
3.5 \pm 1.1 \\
\end{array}$ & $\begin{array}{l}\mathrm{F}=8.0 \\
\mathbf{p}=\mathbf{0 . 0 0 5}\end{array}$ \\
\hline Sex & $\begin{array}{c}14.3 \% \text { vs. } \\
12.7 \%\end{array}$ & $\mathrm{p}=0.56$ & $\begin{array}{c}34.8 \% \text { vs. } \\
16.2 \%\end{array}$ & $\mathrm{P}=0.21$ & $\begin{array}{c}78.6 \% \text { vs. } \\
14.0 \%\end{array}$ & $\mathrm{P}=0.3$ \\
\hline Sleep disturbances & $\begin{array}{c}63.4 \% \text { vs. } \\
39.5 \%\end{array}$ & $\mathrm{p}=0.10$ & $\begin{array}{c}47.6 \% \mathrm{vs} . \\
42.7 \%\end{array}$ & $\begin{aligned} \mathrm{X}^{2} & =0.15 \\
\mathrm{p} & =0.67\end{aligned}$ & $\begin{array}{c}54.3 \% \text { vs. } \\
40.3 \%\end{array}$ & $\begin{array}{l}\mathrm{X}^{2}=2.2 \\
\mathrm{p}=0.14\end{array}$ \\
\hline $\begin{array}{l}\text { Psychoactive medication } \\
\text { (anxiolytics, sleeping } \\
\text { pills, antidepressants) }\end{array}$ & $\begin{array}{c}28.6 \% \text { vs. } \\
30.7 \%\end{array}$ & $\mathrm{p}=0.57$ & $\begin{array}{c}47.6 \% \text { vs. } \\
28.0 \%\end{array}$ & $\mathrm{p}=0.06$ & $\begin{array}{c}40.0 \% \text { vs. } \\
27.9 \%\end{array}$ & $\begin{array}{l}\mathrm{X}^{2}=1.9 \\
\mathrm{p}=0.16\end{array}$ \\
\hline Parafunctions & $\begin{array}{c}42.9 \% \text { vs } \\
71.3 \%\end{array}$ & $\begin{aligned} X^{2} & =4.85 \\
\mathbf{p} & =\mathbf{0 . 0 3}\end{aligned}$ & $\begin{array}{c}66.7 \% \mathrm{vs} . \\
69.2 \%\end{array}$ & $\begin{array}{c}\mathrm{X}^{2}=0.06 \\
\mathrm{p}=0.81\end{array}$ & $\begin{array}{c}57.1 \% \text { vs. } \\
72.1 \%\end{array}$ & $\begin{array}{c}\mathrm{X}^{2}=2.87 \\
\mathrm{p}=0.07\end{array}$ \\
\hline $\begin{array}{l}\text { Pain in response to mus- } \\
\text { cle palpation }\end{array}$ & $\begin{array}{c}85.7 \% \text { vs. } \\
64.7 \% \\
\end{array}$ & $\mathrm{p}=0.09$ & $\begin{array}{c}61.9 \% \text { vs. } \\
67.1 \% \\
\end{array}$ & $\mathrm{X}^{2}=0.26 \mathrm{p}=0.4$ & $\begin{array}{c}71.4 \% \text { vs. } \\
65.1 \% \\
\end{array}$ & $\begin{aligned} \mathrm{X}^{2} & =0.49 \\
\mathrm{p} & =0.31\end{aligned}$ \\
\hline $\begin{array}{l}\text { Number of tender muscle } \\
\text { points }\end{array}$ & $\begin{array}{c}3.0 \pm 2.7 \mathrm{vs} \\
2.9 \pm 3.0\end{array}$ & $\begin{array}{l}\mathrm{F}=0.03 \\
\mathrm{p}=0.86\end{array}$ & $\begin{array}{c}2.0 \pm 2.0 \mathrm{vs} \\
3.0 \pm 3.0\end{array}$ & $\begin{array}{l}\mathrm{F}=2.26 \\
\mathrm{p}=0.13\end{array}$ & $\begin{array}{c}2.4 \pm 2.4 \text { vs. } \\
3.0 \pm 3.1\end{array}$ & $\begin{array}{c}\mathrm{F}=1.19 ; \\
\mathrm{p}=0.28\end{array}$ \\
\hline $\begin{array}{l}\text { Panoramic X-ray alte- } \\
\text { rations }\end{array}$ & $64.3 \%$ vs $14 \%$ & $\begin{array}{l}X^{2}=21.7 \\
\mathbf{p}=\mathbf{0 . 0 0 0}\end{array}$ & $\begin{array}{c}57.14 \% \mathrm{vs} . \\
12.6 \%\end{array}$ & $\begin{array}{l}X^{2}=24.3 \\
\mathbf{p}=\mathbf{0 . 0 0 0}\end{array}$ & $60 \%$ vs. $7.0 \%$ & $\begin{array}{l}X^{2}=51.8 \\
\mathbf{p}=\mathbf{0 . 0 0 0}\end{array}$ \\
\hline
\end{tabular}

Table 3. Comparison with patients presenting other temporomandibular joint disorders (TMD).

The absence of differences between osteoarthritis and osteoarthrosis, and the definition of both given by the RDC/TMD (3), suggest that these are actually the same process in two different clinical moments (presence/ absence of pain). By definition, osteoarthritis is an inflammatory disorder, though none of the signs of inflammation (except pain) are included among the diagnostic criteria of osteoarthritis proposed by the RDC/TMD. The presence of alterations in the imaging studies, together with pain, are sufficient criteria for establishing a diagnosis of osteoarthritis, though $\mathrm{P}-\mathrm{Xr}$ alterations are very frequent in the general population - such alterations in many cases being regarded as simple adaptive processes. As a result, an episode of arthralgia can be mistakenly diagnosed as corresponding to osteoarthritis. Many systemic and orofacial disorders are characterized by periods of silence and exacerbation (e.g., lichen planus, lupus erythematosus, bullous pemphigoid, etc.) that require different management approaches but not different denominations. If osteoarthritis and osteoarthrosis as defined by the RDC/TMD correspond to the same process, then it would be advisable to avoid using different names which imply different clinicopathological conditions.

In conclusion, no significant differences are observed between osteoarthritis and osteoarthrosis, though both processes show differences with respect to the group of patients with temporomandibular joint pathology from which they were drawn. The limited number of patients in each group and the clinical tendencies detected point to the need for further studies. 


\section{References}

1. Rantala MA, Ahlberg J, Suvinen TI, Savolainen A, Könönen M Symptoms, signs, and clinical diagnoses according to the research diagnostic criteria for temporomandibular disorders among Finnish multiprofessional media personnel.J Orofac Pain. 2003;17:311-6.

2. Dijkgraaf LC, Spijkervet FK, de Bont LG. Arthroscopic findings in osteoarthritic temporomandibular joints. J Oral Maxillofac Surg. 1999;57:255-68;

3. Dworkin SF, LeResche L. Research diagnostic criteria for temporomandibular disorders: review, criteria, examinations and specifications, critique. J Craniomandib Disord. 1992;6:301-55.

4. Poveda Roda R, Díaz Fernández JM, Hernández Bazán S, Jiménez Soriano Y, Margaix M, Sarrión G. A review of temporomandibular joint disease (TMJD). Part II: Clinical and radiological semiology. Morbidity processes. Med Oral Patol Oral Cir Bucal. 2008;13:E102-9.

5. Poveda-Roda R, Bagán JV, Jiménez-Soriano Y, Fons-Font A. Retrospective study of a series of 850 patients with temporomandibular dysfunction (TMD). Clinical and radiological findings. Med Oral Patol Oral Cir Bucal. 2009;14:e628-34.

6. Martinez Blanco M, Bagán JV, Fons A, Poveda Roda R. Osteoarthrosis of the temporomandibular joint. A clinical and radiological study of 16 patients. Med Oral. 2004;9:110-15, 106-10.

7. Machado LP, Nery Cde G, Leles CR, Nery MB, Okeson JP. The prevalence of clinical diagnostic groups in patients with temporomandibular disorders. Cranio. 2009;27:194-9.

8. Yu S, Xing X, Liang S, Ma Z, Li F, Wang M, et al. Locally synthesized estrogen plays an important role in the development of TMD. Med Hypotheses. 2009;72:720-2.

9. Henry CH, Tull GT, Whittum-Hudson JA, Wolford LM. Analysis of estrogen binding sites of the posterior ligament of the human TMJ. Oral Surg Oral Med Oral Pathol Oral Radiol Endod. 2008;105:698-701.

10. Smith MT, Wickwire EM, Grace EG, Edwards RR, Buenaver LF, Peterson S, et al. Sleep disorders and their association with laboratory pain sensitivity in temporomandibular joint disorder. Sleep. 2009;32:779-90.

11. Ohayon MM, Reynolds CF 3rd. Epidemiological and clinical relevance of insomnia diagnosis algorithms according to the DSMIV and the International Classification of Sleep Disorders (ICSD). Sleep Med. 2009;10:952-60.

12. Abad VC, Sarinas PS, Guilleminault C. Sleep and rheumatologic disorders. Sleep Med Rev. 2008;12:211-28.

13. Johansson Cahlin B, Samuelsson N, Dahlström L. Utilization of pharmaceuticals among patients with temporomandibular disorders: a controlled study. Acta Odontol Scand. 2006;64:187-92.

14. Wang MQ, Xue F, He JJ, Chen JH, Chen CS, Raustia A. Missing posterior teeth and risk of temporomandibular disorders. J Dent Res. 2009;88:942-5.

15. Ahmad M, Hollender L, Anderson Q, Kartha K, Ohrbach R, Truelove EL,et al. Research diagnostic criteria for temporomandibular disorders (RDC/TMD): development of image analysis criteria and examiner reliability for image analysis. Oral Surg Oral Med Oral Pathol Oral Radiol Endod. 2009;107:844-60.

16. Campos MI, Campos PS, Cangussu MC, Guimarães RC, Line SR. Analysis of magnetic resonance imaging characteristics and pain in temporomandibular joints with and without degenerative changes of the condyle. Int J Oral Maxillofac Surg. 2008;37:529-34.

17. Manfredini D, Basso D, Salmaso L, Guarda-Nardini L. Temporomandibular joint click sound and magnetic resonance-depicted disk position: which relationship? J Dent. 2008;36:256-60. 